\title{
Extent Of Director Involvement In The Strategic Management Process: Does Occupational Background Make A Difference?
}

\author{
Nabil A. Ibrahim, (Email: nibrahim@aug.edu), Augusta State University \\ John P. Angelidis, (Email: angelidj@stjohns.edu), St. John's University \\ Donald P. Howard, (Email: dhoward@aug.edu), Augusta State University
}

\begin{abstract}
Propositions were tested with original survey data from 224 directors from nineteen hospitals to determine the extent of their involvement in the strategic management process. In most areas, board members whose occupational background is in health care tend to be less engaged than their counterparts whose background is not in health care. Significant differences were observed with respect to broad cross-functional strategic issues and overall hospital performance. Both groups had limited involvement in setting standards for rewarding top management and evaluating their performance. The results raise potentially important strategic and ethical dilemmas for hospitals and offer proponents of changes in board composition support for their normative suggestions.
\end{abstract}

\section{INTRODUCTION}

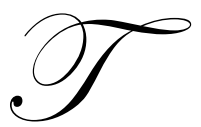

here is general agreement among organizational researchers, governance experts, and business executives that, traditionally, boards have engaged in the strategic process only to the extent that they legitimized proposals from corporate executives (Iacocca, 1984; Shanklin \& Ryans, 1981). However, in recent years, the extent to which board members are involved in the corporate strategic decision making process has become of major concern. This has sparked many research investigations. Of particular interest is the board's decision making processes (Forbes \& Milliken, 1999), the structure of its committee membership (Kesner, 1988), its role in strategic management (Judge \& Zeithaml, 1992), and its impact on financial performance (Hillman \& Dalziel, 2003), CEO succession (Ocasio, 1999), and social responsibility (Ibrahim \& Angelidis, 1995).

\section{BOARD INVOLVEMENT}

To date, the board's multiple roles and duties have been the most-studied aspect among all board investigations. These studies identified several major responsibilities that capture directors' most significant functions. A list of some of these is presented in Table 1.

There is ample empirical evidence from organizations of many different kinds that there are levels of board involvement, which can be represented as continua (McNulty \& Pettigrew, 1999; Zahra \& Pearce, 1989). One particularly useful framework for evaluating the role of the board of directors in corporate strategic management was developed by Wheelen and Hunger (2004). A board can be characterized as being at a specific point on a continuum depending upon its degree of involvement in strategic affairs. Accordingly, "boards can range from phantom boards with no real involvement to catalyst boards with a very high degree of involvement" (p. 28). aspects of strategic management. Table 2 shows these scales and the areas they purport to measure. 
Table 1. Responsibilities Of Boards Of Directors

\begin{tabular}{|c|c|c|}
\hline Author(s) & Year & Responsibilities \\
\hline Pfeffer and Salancik & 1978 & $\begin{array}{l}\text { Advice and counsel } \\
\text { Oversight and control. }\end{array}$ \\
\hline Ong and Lee & 2000 & Monitoring the actions of executives on behalf of shareholders \\
\hline Hillman and Dalziel & 2003 & Providing input, resources, and advice in formulating strategies \\
\hline Johnson et al. & 1996 & $\begin{array}{l}\text { Establishing links with stakeholders } \\
\text { Participating in strategic planning }\end{array}$ \\
\hline Boulton & 1978 & $\begin{array}{l}\text { Reviewing overall board role and responsibilities } \\
\text { Reviewing operating variances and problem areas } \\
\text { Reviewing objectives and setting standards of performance } \\
\text { Reviewing business structure } \\
\text { Evaluating strategic and operating plans } \\
\text { Reviewing standards for compensation and rewarding performance } \\
\text { Ensuring the organization's human resource development } \\
\text { Reviewing external trends } \\
\text { Setting policies for corporate action }\end{array}$ \\
\hline
\end{tabular}

Table 2. Scales Measuring Board Involvement

\begin{tabular}{ll} 
Author(s) & Yea \\
\hline Judge and & \\
Zeithmal & 1992 \\
& \\
Westphal & 1999 \\
Blake & 1999
\end{tabular}

Purpose of Scale

To measure board involvement in the formulation and evaluation phases of the strategic decision-making process

To measure the degree to which directors: monitor top management's strategic decision making formally evaluate the performance of top executives defer to the judgment of top managers on final strategic decisions develop performance objectives require information showing progress against corporate objectives analyze financial information for important issues and trends analyze budget allocation against performance review company performance against the strategic plan.

Westphal

Dulewicz

et al.

1999

Zahra

Blake
To measure the extent to which:

top executives solicit board assistance in strategy formulation outside directors serve as a sounding board on strategic issues directors provide advice and counsel outside of board and committee meetings the board takes into account stakeholders' legitimate interests the board ensures that communications with stakeholders are effective the board promotes the goodwill and support of relevant stakeholders

To measure the degree to which the board: articulates a company mission analyzes the internal and external environments identifies a strategic plan develops strategic options and selects a final strategy is involved in the strategic planning process communicates the company's strategic direction throughout the company receives plans for the implementation of strategy from the CEO benchmarks the strategic plan with industry comparative data. 
A sizable amount of study has been devoted to board involvement. Unfortunately, when viewed as a whole, the results are mixed and inconclusive, thus limiting the number of definitive conclusions that can be drawn. Some have found that executives are resisting increased board involvement in the strategic process. Other evidence suggests that board members are reacting to various external pressures with active participation. Table 3 shows a list of the key studies.

\section{BOARD CHARACTERISTICS AND COMPOSITION}

The boards of many types of organizations have been examined from a wide variety of perspectives. More than two decades ago a number of writers expressed the need to study the profiles of corporate upper echelons in order to understand an organization's strategic processes. For example, Hambrick and Mason (1984) proposed several hypotheses for testing the relationship between organizational outcomes and certain demographic characteristics of top executives. They argued that strategic decisions reflect the background of the organization's most influential leaders and the organization's policies and central values could be explained, at least in part, by the profile of its upper echelon.

One common theme that has emerged from research on decision making is that executives are likely to develop distinctly different preferences based on their current or past primary functional areas. These preferences, in turn, are likely to affect their choices. As far back as 1958, Dearborn and Simon reported that top executives tend to define problems in terms of the activities and concerns of their own functional areas. This finding was supported later by a number of studies which found that, although top executives are presumed to be generalists, their occupational background biases their strategic orientation (Snow \& Hrebiniak, 1980; Chaganti \& Sambharya, 1987; Norburn, 1986).

Consistent with this view, a relatively small body of literature has focused on the background of one segment of the firm's upper echelon - its board of directors. Of particular interest to researchers is the impact of the board's composition and characteristics on corporate activities. However, with the exception of studies focusing on the gender of board members and the inside director-outside director dichotomy, much of the research tends to treat directors as a homogeneous group in spite of evidence to the contrary.

Table 3. Board Participation In Strategic Decisions

\begin{tabular}{lll} 
Author(s) & Year & Findings \\
\hline
\end{tabular}

\section{A. Studies Showing Minimal Board Participation}

$\begin{array}{lll}\begin{array}{l}\text { Whisler } \\ \text { Mace }\end{array} & \begin{array}{l}1984 \\ 1986\end{array} & \begin{array}{l}\text { "Rules of the game" is to minimize participation in setting strategy } \\ \text { Boards do not participate in strategic decisions unless faced with a risis }\end{array} \\ \begin{array}{l}\text { Patton and Baker } \\ \text { Lorsch }\end{array} & 1987 & \text { Members are reluctant to "rock the boat" and get involved } \\ \text { Judge and } & 1989 & \begin{array}{l}\text { Directors want to increase their involvement but are reluctant to do so. } \\ \text { The great majority of boards are not actively working with management Zeithaml } \\ \text { to develop strategic action. }\end{array} \\ \text { Daily and Dalton } & \begin{array}{l}\text { Norms of reciprocity: Board appointments confer prestige and status, financial } \\ \text { rewards and various perquisites. Members feel socially obligated to support the } \\ \text { CEO and minimize any meaningful participation }\end{array}\end{array}$

Wall Street 1996

Journal

Social ties between top managers and outside directors tend to be

"chummy" or even "collusive" thus diminishing board effectiveness 


\section{B. Studies Showing Active Board Participation}

Worthy and

Westphal

Heidrick and

1990

Struggles

Dobrzynski

1989
A major increase has taken place in the duties, power, and responsibilities Neuschel of corporate boards

Social ties between the CEO and the board encourage collaboration between top managers and outside directors in strategic decision making

Board members are increasingly involved in determining and monitoring the strategic directions of the organization.

"Quietly, many boards are asserting themselves - redirecting strategy here, vetoing an investment there" (p. 66).

Table 4. Studies Of Hospital Governing Boards

\begin{tabular}{|c|c|c|c|}
\hline Author(s) & Year & Focus & Findings \\
\hline Witt & 1993 & $\begin{array}{l}\text { Board training } \\
\text { policies }\end{array}$ & $\begin{array}{l}\text { Most hospitals did not have any policies for training } \\
\text { and developing board members. Most directors did } \\
\text { not have any board experience in large organizations }\end{array}$ \\
\hline Molinari at al. & 1992 & $\begin{array}{l}\text { Board training } \\
\text { programs }\end{array}$ & $\begin{array}{l}\text { Boards whose members attended training programs } \\
\text { were better informed about management issues and } \\
\text { changes in the external environment, and were associated } \\
\text { with improved financial performance }\end{array}$ \\
\hline Molinari at al. & 1997 & $\begin{array}{l}\text { Relationship } \\
\text { with CEO }\end{array}$ & $\begin{array}{l}\text { CEO participation on boards was associated with } \\
\text { enhanced hospital financial performance }\end{array}$ \\
\hline Gardner & 1992 & Board & $\begin{array}{l}\text { The importance of including nurses in hospital boards } \\
\text { Composition because they have a health care background }\end{array}$ \\
\hline Goes and Zhan & 1995 & $\begin{array}{l}\text { Board } \\
\text { composition }\end{array}$ & $\begin{array}{l}\text { Physician membership on boards was associated with } \\
\text { higher operating margins and occupancy }\end{array}$ \\
\hline $\begin{array}{l}\text { Molinari at al. } \\
\text { Delbeq and } \\
\text { Gill }\end{array}$ & $\begin{array}{l}1993 \\
1988\end{array}$ & $\begin{array}{l}\text { Board } \\
\text { composition }\end{array}$ & $\begin{array}{l}\text { A high proportion of directors with business-related } \\
\text { occupations provided boards with up-to-date opera- } \\
\text { tional information and financial and strategic expertise }\end{array}$ \\
\hline $\begin{array}{l}\text { Gautam and } \\
\text { Goodstein }\end{array}$ & 1996 & $\begin{array}{l}\text { Board } \\
\text { composition }\end{array}$ & $\begin{array}{l}\text { Boards with a higher proportion of insiders and } \\
\text { business directors made more changes in their mix of } \\
\text { services in response to legislative reform }\end{array}$ \\
\hline Ibrahim et al. & 2000 & $\begin{array}{l}\text { Social respon- } \\
\text { siveness } \\
\text { orientation }\end{array}$ & $\begin{array}{l}\text { Compared to those with a healthcare background, } \\
\text { directors who did not have such a background were } \\
\text { more concerned with economic and legal issues }\end{array}$ \\
\hline
\end{tabular}

\section{HOSPITAL DIRECTORS}

One important segment of the literature has been devoted to the study of hospital governing boards. Table 4 presents some of the key studies. Although these investigations have been instrumental in focusing attention on the composition and characteristics of hospital boards, there is still one area which has remained relatively unexplored - the relationship between board members' occupational background and the extent of their involvement in corporate strategy. 
The present study was designed to investigate this issue. Specifically, its purpose is to determine whether a relationship exists between the occupational background of hospital directors and their degree of involvement in the strategic management process. Drawing on studies involving hospital boards and other previous research (Boulton, 1978; Patton \& Baker, 1987; Judge \& Zeithaml, 1992; Westphal, 1999; Blake, 1999; Zahra, 1990; Tricker, 1994; Dulewitz at al., 1995; Fama \& Jensen, 1983), we would expect directors who do not have a healthcare background (NHCB) to be more involved in the strategic process than their counterparts who do have a healthcare background (HCB). Thus, a number of propositions were framed to address the following areas: Broad cross-functional strategic matters, overall hospital performance, performance of top executives, and internal issues. They are presented in Table 5. The health care-no health care dichotomy is in line with previous research on hospital governing boards (Gautam \& Goodstein, 1996; Ibrahim et al., 2000; Saleh et al., 2002).

\section{SAMPLE AND RESULTS}

A total of 262 directors from nineteen hospitals in four southeastern and two northeastern states were asked to participate in the study. Two hundred-and-twenty-four responses were received ( $85.5 \%$ response rate). Interestingly, the response rate from each hospital was in the 81-to-89 percent range. On the average, the hospitals had 402 set-up-andstaffed beds. In the questionnaire which was developed to measure the variables of interest, directors were asked to indicate their age, education, length of service on the hospital's board, and occupational background. To test this study's propositions, a seventeen-item scale was constructed to measure the extent of a board member's participation in corporate strategic management. Responses were made on a four-point scale on which the higher the number the greater the perceived involvement.

Table 5. Propositions Regarding Directors Involvement In The Strategic Process

\section{Broad cross-functional strategic matters}

Compared to directors who do have a healthcare background, those without a healthcare background will be more involved in:

P1A: $\quad$ Reviewing the board's overall role and responsibilities

PlB: $\quad$ Defining/reviewing the hospital's mission/vision statement

PlC: $\quad$ Conducting an analysis of the internal environment

P1D: $\quad$ Conducting an analysis of the external environment

P1E: $\quad$ Taking into account the legitimate interests of major stakeholders

PlF: $\quad$ Promoting the goodwill and support of major stakeholders

PlG: $\quad$ Developing strategic alternatives

PlH: $\quad$ Providing advice and counsel in discussions outside of board/committee meetings

Overall hospital performance

Compared to directors who do not have a healthcare background, those with a healthcare background will be more involved in:

P2A: $\quad$ Benchmarking the strategic plan with industry comparative data

$P 2 B: \quad$ Setting standards for overall hospital performance

$P 2 C: \quad$ Evaluating overall hospital performance against the strategic plan

$P 2 D: \quad$ Analyzing financial information for important issues and trends

P2E: $\quad$ Evaluating operating variances

Performance of top executives

Compared to directors who do not have a healthcare background, those with a healthcare background will be more involved in:

P3A: $\quad$ Setting standards for rewarding top management's performance

P3B: $\quad$ Formally evaluating the performance of top management

\section{Internal matters}

Compared to directors who do not have a healthcare background, those with a healthcare background will be more involved in: P4A: Reviewing the hospital's overall structure

P4B: $\quad$ Ensuring the hospital's development of human resources 
The respondents were predominantly male (86.3\%) and white (90\%) with an average age of 56.4 years. On the average, they had served for 7.0 years on their respective boards. Ninety-six percent had an undergraduate college degree, 28 percent were medical doctors, and 33 percent earned a graduate or professional degree. Approximately three-quarters (77\%) of these boards meet monthly, 16 percent meet bimonthly, and 7 percent hold quarterly meetings. Finally, in terms of their occupational background, $96(43 \%)$ were in the health care industry. Among the other 128 respondents, virtually all $(91 \%)$ had a business background. The latter included directors with expertise in areas such as accounting, marketing, finance, law, public relations, and management consulting. The results of $t$-tests and chi-square tests showed no significant differences between the HCB and NHCB groups with respect to their ages, gender, years of tenure, and level of education.

Descriptive statistics for all seventeen measures of director involvement are displayed in Table 6. The table also shows the rankings (based on the means of scores) of the responses provided by each group. The analysis of these results was performed in three stages. First, the Spearman rank-order correlation test was conducted to determine to what extent the rankings are similar. The results $\left(r_{s}=0.8596, p=0.0006\right)$ indicate that there are no significant differences between the two sets and that they are positively correlated. That is, there is a high degree of consistency between the two groups' rankings. Closer examination of Table 6 shows that the means of the two groups' scores on each of the items are different. For this reason, a second test was conducted to explore these differences. A multivariate analysis of variance (MANOVA) procedure was considered to be the most appropriate analytic technique. It compensates for variable intercorrelation and provides an omnibus test of any multivariate effect. The MANOVA revealed significant differences between the HCB and NHCB directors (Wilks' $\Lambda=0.4882, p=0.0387$ ). That is, overall, the two groups exhibited different degrees of involvement.

Finally, to understand the underlying contributions of the variables to the significant multivariate effect, each of the seventeen dependent variables was tested using a series of one-way analyses of variance (ANOVAs) with the two groups as our two levels of the independent variable. The results, depicted in Table 7, show that differences between the HCB and NHCB samples were significant on fourteen of the seventeen variables. No significant differences were found in the following areas: setting standards for rewarding top management's performance, formally evaluating the performance of top management, and ensuring the hospital's development of its human resources. However, it is important to note that, in fifteen of the seventeen areas, the NHCB directors' mean scores were greater than the HCB group's mean scores.

\section{DISCUSSION AND CONCLUSION}

The present study is an attempt to partially fill a void by examining similarities and differences among hospital directors based on their occupational background. It led to several insights about this relationship. When the rankings shown in Table 6 are analyzed, several patterns emerge. Overall, the scores of directors with a health care background are lower than those of their counterparts but there is a very high degree of agreement between the two groups in terms of the "ranking" of the items. Specifically, the top seven items of the HCB sample correspond to the top seven items of the NHCB directors (PlA through PlG). These are most directly related to broad, cross-functional strategic issues such as developing strategic alternatives, defining/reviewing the hospital's mission-vision statement, reviewing the board's overall role and responsibilities, and analyzing the internal and external environments. Also, they address the hospital's relationship with its major stakeholders. 
Table 6. Means ${ }^{\mathrm{a}}$, Standard Deviations, And Rankings Of Scores Of Directors

Overall HCB Directors

NHCB Directors

Score

$(n=96)$

$(n=128)$

\section{Variable}

Mean SD Rank Mean SD Rank Mean SD

Reviewing the board's overall role and responsibilities

Defining/reviewing the hospital's mission/vision statement

$3.12 \quad 1.12$

$3.11 \quad 0.97$

Conducting an analysis of the internal environment

$2.91 \quad 0.96$

Conducting an analysis of the external environment

$3.09 \quad 0.84$

Taking into account the legitimate interests of major stakeholders

$2.91 \quad 0.94$

Promoting the goodwill and support of major stakeholders

$2.93 \quad 0.90$

$3.01 \quad 0.74$

Developing strategic alternatives

2.31

Benchmarking the strategic plan with industry comparative data

Setting standards for overall hospital performance

$2.57 \quad 0.91$

$2.49 \quad 1.05$

$2.38 \quad 1.00$

Analyzing financial information for impont

Evaluating operating variances

Reviewing the hospital's overall structure

$1.90 \quad 0.92$

$2.19 \quad 0.54$

Setting standards for rewarding top management's performance

Formally evaluating the performance of top management

$\begin{array}{ll}1.38 & 0.28\end{array}$

$\begin{array}{ll}1.25 & 0.54\end{array}$

$1.52 \quad 0.72$

Rank Mean

1.04

-

$\begin{array}{rrrrrr}4 & 2.69 & 1.04 & 1 & 3.44 & 1.17 \\ 3 & 2.82 & 1.12 & 2 & 3.32 & 0.84 \\ 7 & 2.53 & 0.86 & 4 & 3.20 & 1.02 \\ 2 & 2.87 & 0.84 & 3 & 3.25 & 0.96 \\ 5^{\text {b }} & 2.66 & 0.65 & 6 & 3.09 & 1.10 \\ 5^{\text {b }} & 2.66 & 0.73 & 5 & 3.14 & 1.01 \\ 1 & 2.95 & 0.41 & 7 & 3.05 & 0.30 \\ 8 & 2.50 & 0.76 & 12 & 2.16 & 1.13 \\ 10 & 2.43 & 1.09 & 8 & 2.92 & 0.98 \\ 11 & 2.38 & 0.88 & 9 & 2.72 & 0.92 \\ 12 & 2.30 & 0.99 & 10 & 2.64 & 1.08 \\ 13 & 2.21 & 1.17 & 11 & 2.50 & 0.84 \\ 14 & 1.74 & 0.96 & 13 & 2.02 & 0.88 \\ 9 & 2.47 & 0.47 & 14 & 1.98 & 0.58 \\ 16 & 1.35 & 0.24 & 16 & 1.41 & 0.31 \\ 17 & 1.22 & 0.19 & 17 & 1.27 & 0.69 \\ 15 & 1.44 & 0.56 & 15 & 1.58 & 0.81\end{array}$

a The scale ranged from $1=$ no involvement to $4=$ much involvement.

b Denotes a tie. 
Table 7. ANOVA Results For Differences Between Directors Based On Their Background

\section{Group Means ${ }^{\text {a }}$}

\begin{tabular}{|c|c|c|c|c|}
\hline Dependent Variables & $\begin{array}{c}\text { Directors with } \\
\text { Health Care } \\
\text { Background } \\
(n=96) \\
\end{array}$ & $\begin{array}{c}\text { Directors without } \\
\text { Health Care } \\
\text { Background } \\
(n=128) \\
\end{array}$ & $\mathbf{F}$ & $p$ \\
\hline Reviewing the board's overall role and responsibilities & 2.69 & 3.44 & 24.77 & .0000 \\
\hline Defining/reviewing the hospital's mission/vision statement & 2.82 & 3.32 & 14.58 & .0002 \\
\hline Conducting an analysis of the internal environment & 2.53 & 3.20 & 27.00 & .0000 \\
\hline Conducting an analysis of the external environment & 2.87 & 3.25 & 9.55 & .0023 \\
\hline Taking into account the legitimate interests of major stakeholders & 2.66 & 3.09 & 11.62 & .0008 \\
\hline Promoting the goodwill and support of major stakeholders & 2.66 & 3.14 & 15.57 & .0001 \\
\hline Developing strategic alternatives & 2.95 & 3.05 & 4.44 & .0361 \\
\hline $\begin{array}{l}\text { Providing advice and counsel in discussions outside of board/committee } \\
\text { meetings }\end{array}$ & 2.50 & 2.16 & 6.49 & .0115 \\
\hline Benchmarking the strategic plan with industry comparative data & 2.43 & 2.92 & 12.45 & .0005 \\
\hline Setting standards for overall hospital performance & 2.38 & 2.72 & 7.77 & .0058 \\
\hline Evaluating overall hospital performance against the strategic plan & 2.30 & 2.64 & 5.84 & .0165 \\
\hline Analyzing financial information for important issues and trends & 2.21 & 2.50 & 4.66 & .0319 \\
\hline Evaluating operating variances & 1.74 & 2.02 & 5.13 & .0244 \\
\hline Reviewing the hospital's overall structure & 2.47 & 1.98 & 45.90 & .0000 \\
\hline Setting standards for rewarding top management's performance & 1.35 & 1.41 & 2.48 & .1167 \\
\hline Formally evaluating the performance of top management & 1.22 & 1.27 & .48 & .4907 \\
\hline Ensuring the hospital's development of human resources & 1.44 & 1.58 & 2.11 & .1477 \\
\hline
\end{tabular}

\footnotetext{
${ }^{a}$ The scale ranged from $1=$ no involvement to $4=$ much involvement.
} 
Five items ( $P 2 A$ through $P 2 E)$ referred to benchmarking with industry data, setting standards for and evaluating the hospital's performance, and analyzing and evaluating financial information and operating variances. The two groups' rankings were somewhat similar. With respect to developing human resources $(P 4 B)$ and setting standards for - and evaluating - top management's performance $(P 3 A$ and $P 3 B)$, the rankings were identical. These three items were given the lowest scores by both samples. This suggests that both groups were least interested in or preferred to limit their participation in these three areas.

The results of the ANOVAs provided clear support for propositions $P 1 A$ through $P 1 G$. Compared to directors with a healthcare background, those without such a background were more involved in broad cross-functional issues. Likewise, the ANOVAs offered empirical support for propositions $P 2 B$ through $P 2 E$. Proposition $P 2 A$ was not supported; although the analysis found significant differences between the two groups, those with a healthcare background were more involved in benchmarking the strategic plans with industry comparative data.

The analysis does not provide confirmation of Propositions $P 3 A, P 3 B$, and $P 4 B$ since no significant differences between the two groups were found. Finally, propositions $P I H$ and $P 4 A$ were not supported. There was greater participation by the HCB group in providing advice and counsel outside of board/committee meetings and reviewing their hospitals' structures. However, it is interesting to note that, compared to directors who do not have a health care background, those with a health care background ranked these two items much higher.

Overall, directors who have a healthcare background were found to be less involved in developing, shaping, and evaluating corporate strategy than their counterparts who do not have such a background. Various explanations could be advanced for these results. Previous research provides a possible explanation. Unlike those who have a healthcare background, many of whom are inside board members, those who do not have such a background tend to be more businessoriented and to have a broader range of experience (Dearborn \& Simon, 1958; Witt, 1993; Gautam \& Goodstein, 1996). They are likely to be business experts (e.g., directors of other organizations), support specialists (e.g., lawyers, accountants, and bankers) and influential persons in the community (e.g., prominent civic and political leaders, and university professors). They tend to bring with them experiences and access to information from different business environments and are more likely to compel management to consider a wider range of options (Hillman at al., 2000). At the same time, they are more disposed to be more outspoken when an organization's mission and strategy are discussed. Indeed, the percentage of outside directors is considered to be an indicator of board power vis-à-vis top managers (Daily \& Schwenk, 1996; Pearce \& Zahra, 1991).

On the other hand, inside directors work for the CEO - who is likely to chair the board - on a daily basis and would be more prone to conform to the CEO's wishes. They depend directly on the CEO for their career advancements, and will thus be reluctant to oppose and challenge strategic proposals of the CEO. Indeed, the independence of directors has been found to be an essential requirement for board effectiveness (Dalton et al., 1999). This has led critics to charge that insiders cannot adequately monitor top management's performance (Gautam \& Goodstein, 1996), and to calls for the inclusion of at least some outside directors to monitor the performance of the CEO and other managers (e.g. Baysinger \& Hoskisson, 1990).

Therefore, one of this study's findings appears to be consistent with previous research. Those who do not have a healthcare background, who are likely to be outsiders, tend to be more involved in shaping and monitoring corporate strategy than their counterparts with a healthcare background. Since it is possible that their greater involvement can be explained not by their background but by the fact that they tend to be outsiders, future research efforts need to determine if differences in level of involvement exist between inside and outside hospital directors.

Regarding the similarities between the two groups, it is interesting that the three items where the two groups' scores were not significantly different also received the lowest scores from both groups. One possible explanation is that both groups view one of these issues - development of human resources - as the least "strategic" and more related to the day-to-day management of the organization. Consequently, their involvement is focused on the other areas, namely strategic issues and overall organizational performance. With respect to the two other issues - setting standards for evaluating top management's performance and formally evaluating the performance of top management - the results show 
a reluctance by both groups to examine these two areas. This interpretation is supported by studies that show CEO domination of the board and the directors' need to ingratiate themselves or curry favor with the CEO (Westphal, 1999).

Concerning the differences between the two groups, it is possible that directors whose occupational background is in health care are less interested in the organization's strategic direction and more concerned with the immediate need to deliver quality services. This interpretation would be consistent with the view that physicians traditionally have regarded hospitals as work sites for providing patient care, teaching, or doing research (Pauly \& Redisch, 1973). Thus, according to Molinari, Morlock, Alexander, and Lyles (1993), "given physician interests in state-of-the-art diagnostic and therapeutic technologies, it is plausible that medical staff board participation may result in imprudent capital investments that impair the fiscal viability of the hospital" (p. 360). Also, Gautam and Goodstein (1996) contend that medical staff who serve on hospital boards place their greatest emphasis on patient care and technological breakthroughs. This is further supported by Gardner (1992) who argues that nurses have a special role to play on hospital governing boards by keeping the board focused on the well-being of patients. She reports that quality assurance is one area of significance where those with a health care background can make a big difference to the board. According to Gardner, those in the nursing profession believe that "our primary purpose is to serve patients. We can serve as the conscience of the organization to keep it focused on its primary mission of patient care" (p. 27). In contrast, directors with a business background are "concerned about rising health care expenses and curious about how providers are cutting costs" (Cross, 1996). Attention to the bottom line is generally left to professional managers and community trustees (Goes \& Zhan, 1995). This view is in line with studies reporting that hospital directors whose occupations are not in health care - such as accounting, finance, marketing, and law - tend to be socialized in values of competitive and financial efficiency and more attuned and sensitive to the requirements of the legal and regulatory environment (Gautam \& Goodstein, 1996; Delbecq \& Gill, 1988). As mentioned earlier, those with a background in health care tend to be more concerned with issues related to patient well-being and the practice of medicine.

These findings raise an important issue for the expanding literature on the composition of hospital boards of directors. While prior research has focused primarily on the impact of the membership make-up of boards on issues such as social responsibility, training policies, and financial performance, there has been a dearth of research on the occupational background of directors. The relationships we found between directors' occupational background and their degree of participation raise potentially important strategic and ethical dilemmas for hospitals: board members with a health care background are not as concerned with strategic issues as their counterparts who have a business background. Yet hospitals are under increased pressure to focus on financial performance and abide by numerous legal and regulatory requirements. On the other hand, society expects hospitals to provide quality health care and government agencies require them to be attentive to various regulations. Hospital administrators, researchers, regulators, public policy advocates, and other stakeholders advocating changes in board membership may need to consider the implications of such measures. Also, it is important to note the limited involvement of both groups in setting standards for rewarding top management and evaluating their performance.

Certainly, caveats must be offered regarding conclusions generated by this research. Clearly, the differences between the two groups in terms of their degree of involvement reinforce the importance of examining the composition of hospital boards. However, larger samples are needed to assess the robustness of these results. Additional research is necessary to determine whether a director's level of participation does translate into organizational action. Also, since most board decisions are made by committees, in the future researchers may want to investigate the possible impact of group dynamics on member involvement. Finally, board members' degree of involvement was reported by the directors themselves. Although the possibility of bias cannot be completely ruled out, a number of authors have pointed out that self-report measures are indispensable in organizational research (Gupta \& Beehr, 1982; Podsakoff \& Organ, 1986). This is consistent with Steiner and Miner's (1986) assertion that direct observation of top executives at work is not a practical approach; "only self-reports ... can provide an indication of the time ... spent in decision making and planning ..." (p. 195). Indeed, in certain research contexts, self-reports may provide more accurate estimates of population parameters than behavioral measures (Howard et al., 1980). 
In conclusion the findings of this study highlight an area of growing concern to society and all types of organizations. The directors' role in the strategic process is likely to expand due to increased risks of legal liability and the public's (and patients') unrelenting insistence for safe and high quality products and services. In health care, the issue of board members' involvement is likely to gain increased attention because of societal demands on hospitals and many questions regarding the strategic dimensions of decision making. The results are a reminder that major differences exist between directors with a background in healthcare and those without such a background. This offers proponents of changes in board composition support for their normative suggestions.

\section{REFERENCES}

1. Baysinger,B. and Hoskisson, R. The Composition of Boards of Directors and Strategic Control, Academy of Management Review, Vol. 15, No. 1, 72-87, 1990.

2. Blake, A. Dynamic Directors: Aligning Board Structure for Business Success. (Hampshire: MacMillan, 1999).

3. Boulton, W. R. The Evolving Board: A Look at the Board's Changing Roles and Information Needs, Academy of Management Review, Vol. 3, 827-836, 1978.

4. Chaganti, R. and Sambharya R. Strategic Orientation and Characteristics of Upper Management, Strategic Management Journal, Vol. 8, 393-401, 1987.

5. Cross, M. Creating Community Health Partnerships, Healthcare Executive, Vol. 11, 14-17, 1996.

6. Daily, C. and Dalton, D. CEO and Director Turnover In Failing Firms: An Illusion of Change?, Strategic Management Journal, Vol. 16, 393-400, 1995.

7. Daily, C. and Schwenk, C. Chief Executive Officers, Top Management Teams, and Boards of Directors: Congruent or Countervailing Forces?, Journal of Management, Vol. 22, 185-208, 1996.

8. Dalton, D., Daily, C., Johnson, J., and Ellstrand, A. Number of Directors and Financial Performance: A Meta-analysis, Academy of Management Journal, Vol. 42, No. 6, 674- 686, 1999.

9. Dearborn, D. C. and Simon, H. A. Selective Perception: A Note on the Departmental Identifications of Executives, Sociometry, Vol. 21, 140-144, 1958.

10. Delbecq, A. and Gill, S. Developing Strategic Direction for Governing Boards, Hospital and Health Services Administration, Vol. 33, No. 1, 25-34, 1988.

11. Dobrzynski, J. Taking Charge, Business Week, 66-71, July 31989.

12. Dulewicz, V., MacMillan, K., and Herbert, P. Appraising and Developing the Effectiveness of Boards and their Directors, Journal of General Management, Vol. 20, No. 3, 1-19, 1995.

13. Fama, E. and Jensen, M. Separation of Ownership and Control, Journal of Law and Economics, Vol. 26, 301-325, 1983.

14. Forbes, D. and Milliken, F. Cognition and Corporate Governance: Understanding Boards of Directors as Strategic Decision Making Groups, Academy of Management Review, Vol. 24, No. 3, 489-505, 1999.

15. Gardner, D. Nurses: Conscience of the Board, Trustee, Vol. 45, No. 11, 26-28, 1992.

16. Gautam, K. and Goodstein, J. Insiders and Business Directors on Hospital Boards and Strategic Change, Hospital and Health Services Administration, Vol. 41, No. 4, 423-440, 1996.

17. Goes, J.B. and Zhan, C. The Effects of Hospital-Physician Integration Strategies on Hospital Financial Performance, Health Services Research, Vol. 30, No. 4, 507-521, 1995.

18. Gupta, N. and Beehr, T.A. Test of the Correspondence Between Self-Reports and Alternative Data Sources About Work Organizations, Journal of Vocational Behavior, Vol. 20, 1-13, 1982.

19. Hambrick, D. C. and Mason, P. A. Upper Echelons: The Organization as a Reflection of its Top Managers, Academy of Management Review, Vol. 9, 193-206, 1984.

20. Heidrick and Struggles, Inc. The Changing Board. (Chicago, IL: Heidrick and Struggles, Inc., 1990).

21. Hillman, A., Cannella, A., and Paetzold, R. The Resource Dependence Role of Corporate Directors: Strategic Adaptation of Board Composition in Response to Environmental Change, The Journal of Management Studies, Vol. 37, No. 2, 235-255, 2000.

22. Hillman, A. and Dalziel, T. Board of Directors and Firm Performance: Integrating Agency and Resource Dependence Perspectives, Academy of Management Review, Vol. 28, No. 3, 383-396, 2003.

23. Howard, G., Maxwell S., Wiener, R., Boynton, K., and Rooney, W. Is a Behavioral Measure the Best 
Estimate of Behavioral Parameters? Perhaps Not, Applied Psychological Measurement, Vol. 4, 293-311, 1980.

24. Iacocca, L. Iacocca: An Autobiography. (Toronto: Bantam Books, 1984).

25. Ibrahim, N. and Angelidis, J. The Corporate Social Responsiveness Orientation of Board Members: Are There Differences Between Inside and Outside Directors?, Journal of Business Ethics, Vol. 14, 405-410, 1995.

26. Ibrahim, N. Angelidis, J., and Howard, D. The Corporate Social Responsiveness Orientation of Hospital Directors: Does Occupational Background Make a Difference?, Healthcare Management Review, Vol. 25, 2000.

27. Johnson, J., Daily, C., and Ellstrand, A. Boards of Directors: A Review and Research Agenda, Journal of Management, Vol. 22, 409-438, 1996.

28. Judge, W.O., Jr. and Zeithaml, C. P. Institutional and Strategic Choice Perspectives on Board Involvement in the Strategic Choice Process, Academy of Management Journal, 766-794, 1992.

29. Kesner, I.F. Directors' Characteristics and Committee Membership: An Investigation of Type, Occupation, Tenure, and Gender, Academy of Management Journal, Vol. 31, 66-84, 1988.

30. Lorsch, J. W. Patrons or Potentates: the Reality of America's Corporate Boards. (Boston: Harvard University Graduate School of Business Administration, 1989).

31. Mace, M. L. Directors: Myth and Reality. (Boston: Harvard University Graduate School of Business Administration, 1986).

32. McNulty, T. and Pettigrew, A. Strategists on the Board, Organization Studies, Vol. 20, No. 1, 47-74, 1999.

33. Molinari, C., Hendryx, M., and Goodstein, J. The Effects of CEO-Board Relations on Hospital Performance, Health Care Management Review, Vol. 22, No. 3, 7-15, 1997.

34. Molinari, C., Morlock, L., Alexander, J.A., and Lyles, C.A., Hospital Board Effectiveness: Relationships between Governing Board Composition and Hospital Financial Viability, Health Services Research, Vol. 28, No. 3, 357-370, 1993.

35. Molinari, C., Morlock, L., Alexander, J.A., and Lyles, C.A. Hospital Board Effectiveness: Relationships between Board Training and Hospital Financial Viability, Health Care Management Review, Vol. 17, No. 3, 43-48, 1992.

36. Norburn, D. GOGOs, YOYOs, and DODOs: Company Directors and Industry Performance, Strategic Management Journal, Vol. 7, 101-118, 1986.

37. Ocasio, W. Institutionalized Action and Corporate Governance: The Reliance on Rules of CEO Succession, Administrative Science Quarterly, Vol.44, No.2, 384-416, 1999.

38. Ong, C. and Lee, S. Board Functions and Firm Performance: A Review and Directions for Future Research, Journal of Comparative International Management, Vol. 3, 3-24, 2000.

39. Patton, A. and Baker, J. Why Won't Directors Rock the Boat?, Harvard Business Revue, Vol. 65, No. 6, 10 18, 1987.

40. Pauly, M. and Redisch, M. The Not-For-Profit Hospital as a Physicians' Cooperative, American Economic Review, Vol. 63, No. 1, 87-99, 1973.

41. Pearce, J. A. II and Zahra, S. A. The Relative Power of CEOs and Boards of Directors: Associations With Corporate Performance, Strategic Management Journal, Vol. 12, 135-153, 1991.

42. Pfeffer, J. and Salancik, G. R. The External Control of Organizations: A Resource Dependence Perspective. (New York: Harper \& Row Publishers, 1978).

43. Podsakoff, P. and Organ, D. Self-Reports in Organizational Research: Problems and Prospects, Journal of Management Vol. 12, 531-544, 1986.

44. Saleh, S., Vaughn, T., Rohrer, J., and Linden, T. The Effect of Governing Board Composition on Rural Hospitals' Involvement in Provider-Sponsored Managed Care Organizations, Journal of Health Care Management, Vol. 47, No. 5, 321-333, 2002.

45. Shanklin, W. and Ryans,J. Should the Board Consider This Agenda Item?, MSU Business Topics, Vol. 29, No. 1, 35-42, 1981.

46. Snow, C. and Hrebiniak, L. Strategy, Distinctive Competence and Organizational Performance. Administrative Science Quarterly, Vol. 25, 317-336, 1980.

47. Steiner, J. and Miner, J. Management Policy and Strategy. (New York: Macmillan, 1986). 
48. Tricker, R. International Corporate Governance. (Singapore: Prentice-Hall, 1994).

49. Wall Street Journal. (1996, March 7). Beware Of the Trojan Horse in the Boardroom, B1.

50. Westphal, J. Collaboration in the Boardroom: Behavioral and Performance Consequences of CEO-Board Social Ties, Academy of Management Journal, Vol. 42, No. 1, 7-24, 1999.

51. Wheelen, T. and Hunger, J. Strategic Management and Business Policy, $9^{\text {th }}$ ed. (Upper Saddle River, NJ: Pearson, 2004).

52. Whisler, T. L. The Rules of the Game: Inside the Corporate Boardroom. (Homewood, IL: Dow Jones-Irwin, 1984).

53. Witt, J. Board Training Policies and Practices, Health Care Management Review, Vol. 18, No. 4, 21-28, 1993.

54. Worthy, J., and Neuschel, R. Emerging Issues in Corporate Governance. (Chicago: Northwestern University Press, 1984).

55. Zahra, S. Increasing the Board's Involvement in Strategy, Long Range Planning, Vol. 23, 109-117, 1990.

56. Zahra, S. and Pearce, J. Boards of Directors and Corporate Financial Performance: A Review and Integrative Model, Journal of Management, Vol. 15, No. 2, 291-334, 1989. 


\section{NOTES}

